\title{
Enhanced conjugated linoleic acid and biogas production after ruminal fermentation with Piper betle L. supplementation
}

\section{Rayudika Aprilia Patindra Purba ${ }^{1 *}$ (D) Chalermpon Yuangklang ${ }^{2}$ (D) Pramote Paengkoum ${ }^{1}$ (D}

${ }^{1}$ School of Animal Technology and Innovation, Suranaree University of Technology, 30000, Nakhon Ratchasima, Thailand. E-mail: rayudikaapp.007@gmail.com. "Corresponding author.

${ }^{2}$ Department of Agricultural Technology and Environment, Rajamangala University of Technology-Isan University, Nakhon Ratchasima, Thailand.

ABSTRACT: Piper betle L. is edible plant richer in polyphenols that might improve feed utilization in rumen diet. The objective of the present study was to investigate the effect of various Piper betle L. powder (PL) doses on in vitro rumen microorganisms, ruminal biogas and fermentation end-product production, and biohydrogenation including lipolysis-isomerization. The completely randomized design used five levels of PL supplementation (0,25, 50,75 and $100 \mathrm{mg}$ DM) incubated with $400 \mathrm{mg}$ of a basal substrate of Pangola hay and concentrate (50:50). The matrix compounds $(\mathrm{g} / \mathrm{kg}$ DM) of 0.27 catechin, 0.11 rutin, 3.48 quercetin, 0.41 apigenin, 0.04 myricetin, 0.27 kaempferol, 0.76 eugenol and 0.22 caryophyllene derived from PL altered the fermentation pattern, with an increase in degradable nutrients and total volatile fatty acids and acetogenesis without shifting $p H$ during fermentation. These values promoted in vitro gas production, with higher carbon dioxide and lower methane production. Although, hydrogen recovery from lipolysis-isomerization in biohydrogenation was limited, PL successfully promoted stearic acid (C18:0) accumulation by changing the biohydrogenation pathway of fatty acids, causing more C18:1 trans-11 rather than C18:2 trans-11, cis-15. Consequently, this resulted in more conjugated linoleic acid (CLA) cis-9, trans-11, CLA trans-10, cis-12 and CLA trans-11, cis-13. Enhanced PL supply increased total bacteria and fungal zoospores due to a reduction in rumen protozoa. In conclusion, our results demonstrated that PL is a feed additive with potential for ruminants, promising improved ruminal fermentation and biohydrogenation, while reducing methane production.

Key words: fatty acids, feed additive, organic compounds, polyphenol compounds, rumen.

Aumento na produção de ácido linoléico conjugado e biogás após fermentação ruminal com suplementação com Piper betle $\mathrm{L}$.

RESUMO: Piper betle L. é uma planta comestível rica em polifenois que podem melhorar a utilização de alimentos na dieta de ruminantes. $O$ objetivo do presente estudo foi investigar o efeito de várias doses de Piper betle L em . pó (PL) sobre microrganismos do rúmen in vitro, biogás ruminal e produção de produtos finais de fermentação e bio-hidrogenação, incluindo lipólise e isomerização. O delineamento inteiramente casualizado utilizou cinco niveis de suplementação de PL (0, 25, 50, 75 e $100 \mathrm{mg}$ de MS) incubados com $400 \mathrm{mg}$ de um substrato basal do feno de Pangola e concentrado (50:50). Os compostos da matriz ( $\mathrm{g} / \mathrm{kg} \mathrm{MS})$ de 0,27 catequina, 0,11 rutina, 3,48 quercetina, 0,41 apigenina, 0,04 miricetina, 0,27 kaempferol, 0,76 eugenol e 0,22 cariofileno derivado de PL, alteraram o padrão de fermentação com o aumento de nutrientes degradáveis e voláteis totais, ácidos graxos e acetogênese sem alterar o pH durante a fermentação. Esses valores promoveram a produção de gás in vitro, com maior dióxido de carbono e menor produção de metano. Embora a recuperação de hidrogênio da lipólise-isomerização na bio-hidrogenação tenha sido limitada, o PL promoveu com sucesso o acúmulo de ácido esteárico (C18: 0) alterando a via de bio-hidrogenação dos ácidos graxos, causando mais C18: 1 trans-11 do que C18: 2 trans-11, cis -15. Consequentemente, isso resultou em mais ácido linoléico conjugado (CLA) cis-9, trans-11, CLA trans-10, cis-12 e CLA trans-11, cis-13. O suprimento aprimorado de PL aumentou o total de bactérias e zoósporos de fungos devido a uma redução no número de protozoários do rúmen. Em conclusão, nossos resultados demonstram que o PL é um aditivo alimentar com potencial para ruminantes, prometendo fermentação ruminal e bio-hidrogenação aprimoradas, enquanto reduz a produção de metano.

Palavras-chave: ácidos graxos, aditivo em alimentos para animais, compostos orgânicos, compostos de polifenóis, rúmen.

\section{INTRODUCTION}

Piper betle L. is tropical, edible and affordable plant which is reported to contain a host of potent polyphenol compounds, such as flavonoids and essential oils (PURBA \& PAENGKOUM, 2019). LOURENÇO et al. (2014) incubated forage with quercetin and eugenol, which did not affect C18:2 cis-9, cis-12 yield, but altered the biohydrogenation pathway of C18:3 n-3. DURMIC et al. (2008) 
reported that Australian plants selected as CLAdegrading inhibitors were successful in targeting ruminal bacteria such that biohydrogenation yielded more CLA. Unfortunately, the non-specific bioactive compounds were not reported. Since Piper betle L. has other flavonoids and essential oils (namely catechin, rutin, apigenin, myricetin, kaempferol and caryophyllene), it was hypothesized that Piper betle L. might potentially change fermentation pathways with regard to pyruvate stage and biohydrogenation. Therefore, the objective of present study was to investigate the influence of various inclusions of Piper betle L. powder (PL) on in vitro rumen microorganisms, ruminal biogas and fermentation end-product production, as well as biohydrogenation including lipolysis-isomerization.

\section{MATERIALS AND METHODS}

\section{Animal, feed, Piper betle L. powder and experimental design}

Piper betle L. leaves were planted, harvested and sampled from random spots at SUT Organic Farm, Nakhon Ratchasima, Thailand (14 $52^{\circ} 48^{\prime \prime} \mathrm{N}, 102^{\circ} 00^{\prime} 54^{\prime \prime} \mathrm{E}$ at an elevation of 243 $\mathrm{m}$ above sea level). Leaves were removed from the plant and kept at $4{ }^{\circ} \mathrm{C}$ overnight to avoid any nutrient destruction (PURBA \& PAENGKOUM, 2019). The leaves were mechanically ground (Retsch SM 100 mill; Retsch Gmbh, Haan, Germany) into a powder (PL) and particles were passed a 1-mm sieve, and placed into plastic, sealed pouches in the desiccator (Auto dry desiccator model OH-3S, SPC RT, Thailand) until usage time. In addition, three female Saanen goats $(40 \pm 1.51 \mathrm{~kg}$ body weight) were prepared as rumen donors, with ad libitum access to water and a maintenance total mixed ration (TMR) consisting of Pangola hay and concentrate (50:50) (NRC, 2007). This feed was also presented as a basal substrate in the in vitro experiment. Animals were allocated to the TMR for $20 \mathrm{~d}$, including a $15 \mathrm{~d}$ adaptation period and $5 \mathrm{~d}$ of sampling. Formulation and chemical composition of the PL and feeds (basal substrate) are presented in table 1. The study was designed as a completely randomized design with five levels of PL at $0,25,50,75$ and $100 \mathrm{mg}$ DM, incubated with $400 \mathrm{mg}$ of the basal substrate of TMR and hay (50:50).

\section{In vitro experiment and sampling}

The in vitro experiment was conducted using the Hohenheim gas test method of MENKE \& STEINGASS (1988), as modified by PAENGKOUM et al. (2015). On the $16^{\text {th }}, 18^{\text {th }}$ and $20^{\text {th }}$ day of the feeding trials, rumen fluid was extracted from the rumen via oral lavage by suction pump (Hitachi CVSF18, Japan) before morning feeding time, avoiding saliva collection (LODGE-IVEY et al., 2009). Rumen fluid was strained using a nylon membrane (400 $\mu \mathrm{m}$; Fisher Scientific S.L., Madrid, Spain) into Conical flask, and mixed with salivary buffer (1:2, $\mathrm{ml}: \mathrm{ml})$ under $\mathrm{CO}_{2}$ and kept at $39{ }^{\circ} \mathrm{C}$ for $24 \mathrm{~h}$. The composition of the rumen fluid buffer mixture was as follows: $474 \mathrm{ml}$ rumen fluid, $0.60 \mathrm{~g} \mathrm{MgSO}_{4} .7 \mathrm{H}_{2} \mathrm{O}$, $1.32 \mathrm{~g} \mathrm{CaCl}_{2} \cdot 2 \mathrm{H}_{2} \mathrm{O}, 0.10 \mathrm{~g} \mathrm{MnCl}_{2} \cdot 4 \mathrm{H}_{2} \mathrm{O}, 0.10 \mathrm{~g}$ $\mathrm{CoCl}_{2} .6 \mathrm{H}_{2} \mathrm{O}, 0.80 \mathrm{~g} \mathrm{FeCl}_{3} .6 \mathrm{H}_{2} \mathrm{O}, 35 \mathrm{~g} \mathrm{NaHCO}_{3}, 4 \mathrm{~g}$ $\mathrm{NH}_{4} \mathrm{HCO}_{3}, 5.70 \mathrm{~g} \mathrm{Na}_{2} \mathrm{HPO}_{4}, 6.20 \mathrm{~g} \mathrm{KH}_{2} \mathrm{PO}_{4}, 10 \mathrm{mg}$ resazurin and $0.40 \mathrm{~g} \mathrm{NaOH}$, made up to $1000 \mathrm{ml}$ with distilled water (MENKE \& STEINGASS, 1988). The incubation was prepared using a $100 \mathrm{ml}$ glass syringe filled with basal substrate, the PL dose and the rumen fluid/buffer mixture. For example, the treatment group using $100 \mathrm{mg}$ of PL contained $400 \mathrm{mg}$ substrate plus $100 \mathrm{mg}$ PL, mixed with $30 \mathrm{ml}$ rumen fluid/buffer. The sample for incubation was complete after $8 \mathrm{~g} / \mathrm{kg} \mathrm{DM}$ sunflower oil was infused into each glass syringe. Ten replicates of each treatment were prepared in three consecutive runs, with three blank controls added per run, containing only the rumen fluid/buffer mixture.

After $24 \mathrm{~h}$ of incubation, total gas production was read based on the model of ORSKOV \& MCDONALD (1970). A $30 \mathrm{ml}$ sample of gas from the glass syringe was used to measure methane and carbon dioxide levels by gas chromatography (Agilent 7890A, USA). The glass syringe was kept on ice to impede fermentation (JAYANEGARA et al., 2012a). Once the glass syringe was uncapped, the $\mathrm{pH}$ of the fermented content was measured directly using a pH meter (Oakton 700, USA). The fermented content was divided into four portions. The first portion was centrifuged at $6,000 \times \mathrm{g}$ at $4{ }^{\circ} \mathrm{C}$ for 15 min and the supernatant was stored at $-20{ }^{\circ} \mathrm{C}$. For volatile fatty acid (VFA) analysis, the supernatant was fixed with $25 \%$ metaphosphoric acid (ERWIN et al., 1961; FILÍPEK \& DVOŘÁK, 2009). Rumen ammonia detection was performed in accordance with the micro-Kjeldahl method (Foss Kjeltech 8100 , USA) (AOAC, 2005). The second portion was stored at $-20{ }^{\circ} \mathrm{C}$ for fatty acid (FA) analysis. The third portion was treated with $10 \%$ formalin solution in a sterilized $0.9 \%$ saline solution for observation and calculation of total bacteria, protozoa and fungal zoospores using a counting chamber (Neubauer, Germany) as described by WANAPAT et al. (2013). The last portion was prepared for in vitro dry matter degradability (IVDMD) and in vitro organic matter 
degradability (IVOMD) following the method of TILLEY \& TERRY (1963) using pre-weighed Gooch crucibles (Isolab, Gmbh, Germany).

\section{Laboratory analysis and calculation}

The samples of substrate and PL were chemically analyzed for dry matter (DM), organic matter, ash, crude protein (total $\mathrm{N} \times 6.25$ ) and crude fat following prior protocols (AOAC, 2005). Acid detergent fiber and neutral detergent fiber were measured as described previously (VAN SOEST et al., 1991), with residual ash included. The gross energy was determined using a bomb calorimeter with an $\mathrm{O}_{2}$ carrier (Parr 6200 bomb calorimeter, Parr Instruments Co., Moline, IL) according to the manufacturer's instructions. Concentrations of rutin, apigenin, quercetin, kaempferol, myricetin, eugenol and caryophyllene was determined by a mean peak rate of signal following the High Performance Liquid Chromatography with Diode Array Detector principle (PURBA \& PAENGKOUM, 2019). All measurements were performed in triplicate and chemical standards were included in each analytical run as appropriate (Table 1).

Fatty acid (FA) measurement was conducted following the guidelines of FOLCH et al. (1957), as modified by (DE WEIRDT et al., 2013) using gas chromatography (Agilent 7890A, USA) with a CP-Sil88 column for FA methyl esters $(100 \mathrm{~m} \times 0.25 \mathrm{~mm} \times 0.2 \mu \mathrm{m}$; Chrompack Inc., Middelburg, the Netherlands). Heptadecanoic acid (C17:0; Sigma-Aldrich) was applied as an internal standard (LASHKARI \& JENSEN, 2017) and the $\mathrm{C} 17: 0$ value was excluded in the calculation. The column temperature was kept at $70{ }^{\circ} \mathrm{C}$ for $4 \mathrm{~min}$, then increased by $13{ }^{\circ} \mathrm{C} / \mathrm{min}$ to $175^{\circ} \mathrm{C}$ and held for $27 \mathrm{~min}$, then increased by $4{ }^{\circ} \mathrm{C} / \mathrm{min}$ to $215^{\circ} \mathrm{C}$ and held for $17 \mathrm{~min}$, then increased by $4{ }^{\circ} \mathrm{C} / \mathrm{min}$ to $240{ }^{\circ} \mathrm{C}$ and held for $10 \mathrm{~min}$. More detailed information about the detection and calculation methods of peak area is given by LOURENÇO et al. (2014). The FA profile of feed and PL is presented in table 1. Calculation of the efficiency of lipolysis and isomerization (C18:2 n-6 $\rightarrow$ C18:2 cis-9, trans-11), and the hydrogenation processes of $\mathrm{C} 18: 2 \mathrm{n}-6$ and $\mathrm{C} 18: 3 \mathrm{n}-3$ in incubations were calculated as determined by BOECKAERT et al. (2007), as modified by PANYAKAEW et al. (2013) (Table 4).

The supernatant of the $2 \mu \mathrm{L}$ VFA sample was injected into the gas chromatography machine (Hewlett Packard GC system HP6890 A; Hewlett Packard, Avondale, PA, USA), in triplicate, following the previous study by ERWIN et al. (1961), with modification by FILÍPEK \& DVOŘÁK (2009). Acetic acid, propionic acid, iso-butyric acid, butyric, iso-valeric acid and valeric acid (Carlo Ebra, France) were prepared with $1 \%$ formic acid and considered as standards for calibration. Hydrogen recovery (HR) was calculated as (2 Propionate +2 Butyrate + $\left.4 \mathrm{CH}_{4}\right) /(2$ Acetate + Propionate +4 Butyrate), with acetate, propionate, butyrate and $\mathrm{CH}_{4}$ (MARTY \& DEMEYER, 1973). HR measurement was performed in triplicate and expressed as net molar production $(\mathrm{mol} / \mathrm{mol})$.

\section{Statistical analysis}

Statistical analysis accounted for the completely randomized design using the PROC GLM procedure of SAS 9.4. Data were analyzed using the model:

$\mathrm{Y}_{\mathrm{ST}}=\mathrm{A}+\mathrm{B}_{\mathrm{S}}+\mathrm{E}_{\mathrm{ST}}$

where $\mathrm{Y}_{\mathrm{ST}}=$ the dependent variable, $\mathrm{A}=$ the overall mean, $\mathrm{B}_{\mathrm{S}}=$ the influence of the various PL doses $\left(_{\mathrm{S}}=1-5\right)$, and $\mathrm{E}_{\mathrm{ST}}=$ the residual effect. Because the runs were not significantly different, results are presented as mean values with the standard error of the mean. Differences between treatment means were calculated by Tukey's test (KAPS \& LAMBERSON, 2004). Orthogonal polynomial contrasts were used to estimate the linear and quadratic PL effects. All differences with $\mathrm{P}<0.05$ were accepted as representing statistically significant differences.

\section{RESULTS AND DISCUSSION}

\section{Ruminal biogases, fermentation end-products and} microorganisms

The effect of the inclusion of Piper betle L. powder (PL) on fermented substrate in terms of ruminal biogas, fermentation end-products and microorganisms after $24 \mathrm{~h}$, is presented in table 2 . The present matrix of flavonoids and essential oils derived from PL gradually increased total volatile fatty acids (VFAs) corresponding to an increase in degradability, especially of fermented organic matter. In this study, in vitro dry matter degradability (IVDMD) and in vitro organic matter degradability (IVOMD) rose with the increase of PL. These results increased the total VFAs. However, unchanged numbers of total VFAs and degradability efficiencies were found previously, where they were compared to the control after substrate was incubated with quercetin, rutin and eugenol (CASTILLEJOS et al., 2006; OSKOUEIAN et al., 2013). Contradictions could be due to different basal substrates in proportion to the bioactive plant compound. The former studies subjected the ruminants 
Table 1 - Ingredient and chemical composition of concerned treatments.

\begin{tabular}{|c|c|c|}
\hline Item & Feed & Piper betle L. powder \\
\hline \multicolumn{3}{|l|}{ Ingredient, $\mathrm{g} / \mathrm{kg} \mathrm{DM}$} \\
\hline Dehydrated Pangola hay & 500 & \\
\hline Cassava chip & 170 & \\
\hline Rice bran & 70 & \\
\hline Molasses & 40 & \\
\hline Palm meal & 100 & \\
\hline Soybean meal & 100 & \\
\hline Urea & 9 & \\
\hline Sulphur & 1 & \\
\hline Mineral $^{1}$ & 8 & \\
\hline Premix $^{2}$ & 2 & \\
\hline \multicolumn{3}{|c|}{ Chemical composition, $\mathrm{g} / \mathrm{kg}$ DM } \\
\hline Organic matter & 870.7 & 778.8 \\
\hline Crude protein & 129.5 & 25.6 \\
\hline Crude fat & 22.5 & 3.4 \\
\hline Neutral detergent fiber & 684.7 & 639.4 \\
\hline Acid detergent fiber & 545.4 & 509.1 \\
\hline Gross energy, $\mathrm{MJ} / \mathrm{kg} \mathrm{DM}$ & 22.9 & 17.7 \\
\hline \multicolumn{3}{|c|}{ Total polyphenols compounds, $\mathrm{g} / \mathrm{kg}$ DM } \\
\hline Catechin & - & 0.3 \\
\hline Rutin & - & 0.1 \\
\hline Quercetin & - & 3.5 \\
\hline Apigenin & - & 0.4 \\
\hline Myricetin & - & 0.1 \\
\hline Kaempferol & - & 0.3 \\
\hline Eugenol & - & 0.8 \\
\hline Caryophyllene & - & 0.2 \\
\hline \multicolumn{3}{|c|}{ Fatty acid proportion, g/100 g FA } \\
\hline $\mathrm{C} 14.0$ & 4.8 & 1.9 \\
\hline C16.0 & 22.0 & 23.5 \\
\hline C18.0 & 4.1 & 5.1 \\
\hline C18:1n-9 & 20.7 & 13.5 \\
\hline C18:2n-6 & 20.1 & 18.5 \\
\hline C18:3n-3 & 0.2 & - \\
\hline
\end{tabular}

${ }^{1}$ Contained (g/kg): $\mathrm{NaCl}(600), \mathrm{P}(160), \mathrm{Ca}(240)$.

${ }^{2}$ Vitamin A $(4,200.000 \mathrm{IU} / \mathrm{kg})$, vitamin $\mathrm{A}_{3}(840,000 \mathrm{IU} / \mathrm{kg})$, vitamin E $(10,000 \mathrm{IU} / \mathrm{kg})$, vitamin $\mathrm{K}_{3}(2 \mathrm{~g} / \mathrm{kg}), \mathrm{vitamin} \mathrm{B}_{1}(2.4 \mathrm{~g} / \mathrm{kg})$, vitamin $B_{2}(3.5 \mathrm{~g} / \mathrm{kg})$, vitamin $\mathrm{B}_{6}(1.8 \mathrm{~g} / \mathrm{kg})$, vitamin $\mathrm{B}_{12}(0.01 \mathrm{~g} / \mathrm{kg})$, vitamin $\mathrm{B}_{5}(4.6 \mathrm{~g} / \mathrm{kg})$, vitamin $\mathrm{C}(12 \mathrm{~g} / \mathrm{kg})$, folic acid $(0.28 \mathrm{~g} / \mathrm{kg})$, coper $(12 \mathrm{~g} / \mathrm{kg})$, manganese $(40 \mathrm{~g} / \mathrm{kg})$, zinc $(3.2 \mathrm{~g} / \mathrm{kg})$, iron $(42 \mathrm{~g} / \mathrm{kg})$, iodine $(0.8 \mathrm{~g} / \mathrm{kg})$, cobalt $(0.8 \mathrm{~g} / \mathrm{kg})$, selenium $(0.35 \mathrm{~g} / \mathrm{kg})$.

to a $60: 40$ forage: concentrate diet (CASTILLEJOS et al., 2006; OSKOUEIAN et al., 2013), whereas in our study, a 50:50 Pangola hay: concentrate diet was applied. Also, those reports purchased a commercial secondary compound product. Notably, in vitro studies with supplementing active plant compound to modulate rumen performance may result in varied outcomes due to different purity rate, binding behavior and hydroxyl compound (PURBA et al., 2020). Despite PL derived from conventional procedure, PL had been reported owning abundant hydroxyl groups and as carbohydrate sources that enhanced the fermented substrate during fermentation (PURBA \& PAENGKOUM 2019). Hence, this elaboration may also account for why the final results were slightly different. Higher VFAs values reflect a greater amount of fermented substrate by rumen microbes that could also be recognized in the total 
Table 2 - The mean value of substrate incubated with Piper betle L. powder (PL) on ruminal biogases, fermentation end-products and microorganisms after $24 \mathrm{~h}$ incubation.

\begin{tabular}{|c|c|c|c|c|c|c|c|c|}
\hline \multirow[t]{2}{*}{ Parameter $^{1}$} & \multicolumn{5}{|c|}{ 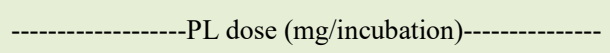 } & \multirow[t]{2}{*}{$\mathrm{SEM}^{2}$} & \multicolumn{2}{|c|}{-----------Contrast ${ }^{3}$-------- } \\
\hline & 0 & 25 & 50 & 75 & 100 & & Linear & Quadratic \\
\hline $\mathrm{pH}$ & 6.9 & 6.8 & 6.8 & 6.9 & 6.9 & 0.013 & 0.438 & 1.000 \\
\hline Total gas production (ml/g OM) & $30.1^{\mathrm{d}}$ & $36.8^{\mathrm{c}}$ & $38.7^{\mathrm{b}}$ & $42.4^{\mathrm{a}}$ & $42.9^{\mathrm{a}}$ & 0.670 & $<0.001$ & $<0.001$ \\
\hline $\mathrm{CO}_{2}(\mathrm{ml} / \mathrm{g} \mathrm{OM})$ & $14.2^{\mathrm{d}}$ & $18.6^{\mathrm{c}}$ & $20.6^{\mathrm{b}}$ & $26.8^{\mathrm{a}}$ & $27.1^{\mathrm{a}}$ & 0.706 & $<0.001$ & $<0.001$ \\
\hline $\mathrm{CH}_{4}(\mathrm{ml} / \mathrm{g} \mathrm{OM})$ & $11.9^{\mathrm{a}}$ & $10.8^{\mathrm{b}}$ & $9.1^{\mathrm{c}}$ & $8.4^{\mathrm{d}}$ & $7.9^{\mathrm{d}}$ & 0.218 & $<0.001$ & $<0.001$ \\
\hline IVDMD (\%) & $49.9^{c}$ & $51.6^{\mathrm{b}}$ & $52.4^{\mathrm{a}}$ & $52.9^{\mathrm{a}}$ & $52.7^{\mathrm{a}}$ & 0.179 & 0.016 & 0.009 \\
\hline IVOMD (\%) & $50.5^{\mathrm{c}}$ & $65.2^{\mathrm{b}}$ & $66.4^{\mathrm{a}}$ & $65.8^{\mathrm{ab}}$ & $64.99^{\mathrm{b}}$ & 0.872 & $<0.001$ & $<0.001$ \\
\hline $\mathrm{NH}_{3}-\mathrm{N}(\mathrm{mg} / 100 \mathrm{ml})$ & $19.7^{\mathrm{b}}$ & $20.7^{\mathrm{a}}$ & $20.5^{\mathrm{a}}$ & $19.9^{\mathrm{b}}$ & $20.0^{\mathrm{b}}$ & 0.066 & 0.996 & 0.029 \\
\hline Total volatile fatty acid (mM) & $61.1^{\mathrm{c}}$ & $66.4^{\mathrm{b}}$ & $69.4^{\mathrm{a}}$ & $69.1^{\mathrm{a}}$ & $68.8^{\mathrm{a}}$ & 0.460 & 0.004 & $<0.001$ \\
\hline Acetate $\left(\mathrm{C}_{2}\right)(\mathrm{mol} / 100 \mathrm{~mol})$ & $52.1^{\mathrm{d}}$ & $54.3^{\mathrm{c}}$ & $56.5^{\mathrm{b}}$ & $57.9^{\mathrm{a}}$ & $58.2^{\mathrm{a}}$ & 0.342 & 0.001 & $<0.001$ \\
\hline Propionate $\left(\mathrm{C}_{3}\right)(\mathrm{mol} / 100 \mathrm{~mol})$ & $20.1^{\mathrm{a}}$ & $19.5^{\mathrm{b}}$ & $19.2^{\mathrm{b}}$ & $18.8^{\mathrm{c}}$ & $18.0^{\mathrm{d}}$ & 0.105 & $<0.001$ & $<0.001$ \\
\hline Iso-butyrate $(\mathrm{mol} / 100 \mathrm{~mol})$ & $5.6^{\mathrm{a}}$ & $4.9^{\mathrm{b}}$ & $4.2^{\mathrm{c}}$ & $3.6^{\mathrm{d}}$ & $3.6^{\mathrm{d}}$ & 0.109 & $<0.001$ & $<0.001$ \\
\hline Butyrate $(\mathrm{mol} / 100 \mathrm{~mol})$ & $10.2^{\mathrm{d}}$ & $10.8^{\mathrm{cd}}$ & $11.4^{\mathrm{c}}$ & $12.3^{\mathrm{b}}$ & $12.9^{\mathrm{a}}$ & 0.141 & $<0.001$ & $<0.001$ \\
\hline Iso-valerate (mol/100 mol) & $4.5^{\mathrm{a}}$ & $4.0^{\mathrm{b}}$ & $3.4^{\mathrm{c}}$ & $2.9^{\mathrm{d}}$ & $3.0^{\mathrm{d}}$ & 0.089 & $<0.001$ & $<0.001$ \\
\hline Valerate $(\mathrm{mol} / 100 \mathrm{~mol})$ & $7.5^{\mathrm{d}}$ & $6.5^{\mathrm{d}}$ & $5.3^{\mathrm{c}}$ & $4.5^{\mathrm{b}}$ & $4.3^{\mathrm{a}}$ & 0.174 & $<0.001$ & $<0.001$ \\
\hline $\mathrm{C}_{2}: \mathrm{C}_{3}$ & $2.6^{\mathrm{d}}$ & $2.8^{\mathrm{cd}}$ & $2.9^{c}$ & $3.1^{\mathrm{b}}$ & $3.2^{\mathrm{a}}$ & 0.032 & $<0.001$ & $<0.001$ \\
\hline $\mathrm{HR}(\mathrm{mol} / \mathrm{mol})$ & $0.66^{\mathrm{a}}$ & $0.61^{\mathrm{b}}$ & $0.55^{\mathrm{c}}$ & $0.52^{\mathrm{c}}$ & $0.50^{\mathrm{d}}$ & 0.008 & $<0.001$ & $<0.001$ \\
\hline Total bacteria, $\times 10^{7}$ cells $/ \mathrm{ml}$ & $5.1^{\mathrm{c}}$ & $5.2^{\mathrm{b}}$ & $5.3^{\mathrm{a}}$ & $5.3^{\mathrm{ab}}$ & $5.2^{\mathrm{b}}$ & 0.021 & $<0.001$ & $<0.001$ \\
\hline Total protozoa, $\times 10^{5}$ cells $/ \mathrm{ml}$ & $5.0^{\mathrm{a}}$ & $4.1^{\mathrm{b}}$ & $4.0^{\mathrm{c}}$ & $3.6^{\mathrm{d}}$ & $3.4^{\mathrm{d}}$ & 0.075 & $<0.001$ & $<0.001$ \\
\hline Total fungal zoospore, $\times 10^{5}$ cells $/ \mathrm{ml}$ & $3.1^{\mathrm{c}}$ & $3.1^{\mathrm{c}}$ & $3.1^{\mathrm{c}}$ & $3.2^{\mathrm{b}}$ & $3.5^{\mathrm{a}}$ & 0.022 & $<0.001$ & $<0.001$ \\
\hline
\end{tabular}

abc Within a row, different superscript represents the significant differences by Tukey $\mathrm{P}<0.05$.

${ }^{1} \mathrm{OM}=$ organic matter; IVDMD= in vitro dry matter degradability; IVOMD = in vitro organic matter degradability; $\mathrm{HR}=\mathrm{hydrogen}$ recovery (calculated in materials and methods (Marty and Demeyer 1973).

${ }^{2} \mathrm{SEM}=$ standard error of mean.

${ }^{3}$ Orthogonal polynomial contrast $\mathrm{P}<0.05$.

production of gas during fermentation. In this study, gas production was promoted by the addition of PL, with more carbon dioxide and less methane gas being produced. A reduction in methane production due to failed methanogenesis through the use of flavonoids and essential oils has been reported in an earlier review (PATRA \& SAXENA, 2010), but the role of rutin, apigenin, myricetin, kaempferol and caryophyllene was not discussed. A smaller proportion of methane gas seems to imply that rumen methanogenesis occurred sluggishly in this study, causing a shift of the profile of VFAs, particularly the acetate, propionate and butyrate fractions.

In the present study, PL during fermentation resulted in higher acetate and butyrate production, but lower propionate, valerate and branched-chain VFAs (the iso-acid fraction). As calculated, this study also showed an inhibited hydrogen supply (HR) to methanogenesis and biohydrogenation. According to prior studies, propionate produced from pyruvate increases hydrogen consumption, and results in less efficient methanogenesis (MOSS et al., 2000; TAVENDALE et al., 2005). However, a meta-analysis by JAYANEGARA et al. (2012b) reported no significant relationship between the propionate surge and methane inhibition. GREENING et al. (2019) confirmed that hydrogen metabolism is a more complex and widespread trait among rumen microorganisms, and claims that the hydrogen yield is usurped by other consumers (not only methanogens) in fumarate and nitrite reduction (Selenomonas spp.) and acetogenesis (Blautia spp.). In the present study, PL supplementation increased the acetate fraction, providing more evidence that hydrogen was consumed by acetogenesis (Blautia spp.) and hydrogen supply was depleted for this reason. Valeric and iso-acid fractions in a recent study (ANDRIES et al., 1987) were lower as consequence of less propionic acid. All changes in fermentation behavior above occurred with an unchanged ruminal $\mathrm{pH}$ across all treatments, while an alteration in $\mathrm{pH}$ 
occurred in the deamination stage after incubation of PL and substrate (Table 2). The range of $\mathrm{pH}$ and ammonia concentration in the present study was 6.8-7.0 mg/100 ml and 19.9-20.1 mg/100 ml, which was acceptable for ruminal microorganisms to survive by modulating microbial growth and fermentation efficiency (WANAPAT \& PIMPA 1999).

Enhanced PL supply reduced protozoa in the rumen (Table 2). A decrease in protozoa number due to the supplementation of secondary compounds has been reported before (CASTILLEJOS et al., 2006; ZHOU et al., 2011; OSKOUEIAN et al., 2013; ANDRÉS et al., 2016; SZCZECHOWIAK et al., 2016) and a primary reason is the ability of bioactive compounds to alter cell wall synthesis or nucleic acid synthesis of protozoa. This reduction in protozoa may be reason why the bacteria and fungal zoospores increased within the incubation period. DEHORITY (2003) mentioned protozoa engulfing rumen bacteria at approximately 20,000 cells per hour. Thus, increased bacteria numbers were contingent on the eliminated protozoa. NEWBOLD et al. (2015) also reported that fungal zoospores were inversely proportional to protozoal number, indicating a competitiveness between protozoa and fungal zoospores for substrate during fermentation. In another report, CHERDTHONG et al. (2019) confirmed that fungal zoospores had a defensive mechanism for survival in the presence of bioactive compounds.

\section{Lipolysis, isomerization and biohydrogenation}

The effect of the addition of Piper betle L. powder (PL) to fermented substrate on the FA profile of rumen fermentation after $24 \mathrm{~h}$ is presented in table 3.

Table 3 - The mean value of substrate incubated with Piper betle L. powder (PL) on ruminal fatty acid profile (g/100 g) after $24 \mathrm{~h}$ incubation.

\begin{tabular}{|c|c|c|c|c|c|c|c|c|}
\hline \multirow[t]{2}{*}{ Parameter $^{1}$} & \multicolumn{5}{|c|}{ 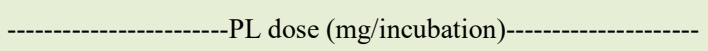 } & \multirow[t]{2}{*}{$\mathrm{SEM}^{2}$} & \multicolumn{2}{|c|}{---------Contrast ${ }^{3}$--------- } \\
\hline & 0 & 25 & 50 & 75 & 100 & & Linear & Quadratic \\
\hline Total SFA ${ }^{4}$ & $65.851^{\mathrm{a}}$ & $62.840^{\mathrm{b}}$ & $61.746^{\mathrm{c}}$ & $61.498^{c}$ & $61.585^{\mathrm{c}}$ & 0.257 & 0.006 & 0.002 \\
\hline C14.0 & $0.919^{c}$ & $0.959^{\mathrm{a}}$ & $0.949^{\mathrm{ab}}$ & $0.940^{\mathrm{b}}$ & $0.919^{\mathrm{c}}$ & 0.003 & 0.132 & 0.171 \\
\hline C16.0 & 20.570 & 20.621 & 20.591 & 20.480 & 20.611 & 0.035 & 1.000 & 0.741 \\
\hline $\mathrm{C} 18.0$ & $36.734^{\mathrm{a}}$ & $33.588^{b}$ & $32.519^{c}$ & $32.388^{\mathrm{c}}$ & $32.368^{\mathrm{c}}$ & 0.245 & $<0.001$ & $<0.001$ \\
\hline Total MUFA ${ }^{5}$ & $22.120^{\mathrm{c}}$ & $25.302^{\mathrm{b}}$ & $26.446^{\mathrm{a}}$ & $26.644^{\mathrm{a}}$ & $26.501^{\mathrm{a}}$ & 0.248 & $<0.001$ & $<0.001$ \\
\hline C18:1 trans $-6-8$ & $0.638^{\mathrm{c}}$ & $0.716^{\mathrm{a}}$ & $0.726^{\mathrm{a}}$ & $0.656^{\mathrm{b}}$ & $0.652^{\mathrm{b}}$ & 0.005 & $<0.001$ & $<0.001$ \\
\hline C18:1 trans -9 & $0.486^{\mathrm{a}}$ & $0.463^{\mathrm{b}}$ & $0.480^{\mathrm{a}}$ & $0.470^{\mathrm{b}}$ & $0.461^{\mathrm{c}}$ & 0.002 & $<0.001$ & 0.529 \\
\hline C18:1 trans -10 & $0.414^{\mathrm{c}}$ & $0.468^{b}$ & $0.491^{\mathrm{a}}$ & $0.490^{\mathrm{a}}$ & $0.485^{\mathrm{a}}$ & 0.004 & 0.001 & $<0.001$ \\
\hline C18:1 trans -11 & $2.476^{\mathrm{e}}$ & $5.428^{\mathrm{d}}$ & $6.439^{c}$ & $6.681^{\mathrm{b}}$ & $6.782^{\mathrm{a}}$ & 0.231 & $<0.001$ & $<0.001$ \\
\hline C18:1 trans -15 & $0.959^{\mathrm{c}}$ & $0.983^{\mathrm{b}}$ & $0.993^{\mathrm{b}}$ & $1.008^{\mathrm{a}}$ & $0.953^{\mathrm{c}}$ & 0.003 & 0.004 & 0.004 \\
\hline C18:1 cis-9 & 5.222 & 5.244 & 5.251 & 5.252 & 5.252 & 0.009 & 1.000 & 0.996 \\
\hline C18:1 cis-11 & $0.762^{\mathrm{c}}$ & $0.752^{\mathrm{c}}$ & $0.769^{\mathrm{b}}$ & $0.787^{\mathrm{a}}$ & $0.695^{\mathrm{d}}$ & 0.005 & $<0.001$ & $<0.001$ \\
\hline C18:1 cis-15 & $0.717^{\mathrm{c}}$ & $0.762^{\mathrm{b}}$ & $0.794^{\mathrm{a}}$ & $0.795^{\mathrm{a}}$ & $0.718^{\mathrm{c}}$ & 0.051 & $<0.001$ & 0.006 \\
\hline Total PUFA ${ }^{6}$ & 12.028 & 11.858 & 11.808 & 11.858 & 11.914 & 0.022 & 1.000 & 0.660 \\
\hline C18:2 trans -11, cis -15 & $0.038^{\mathrm{a}}$ & $0.037^{\mathrm{b}}$ & $0.035^{\mathrm{c}}$ & $0.035^{\mathrm{c}}$ & $0.033^{\mathrm{d}}$ & 0.003 & $<0.001$ & $<0.001$ \\
\hline CLA cis- 9, trans -11 & $0.204^{\mathrm{c}}$ & $0.360^{\mathrm{b}}$ & $0.376^{\mathrm{b}}$ & $0.374^{\mathrm{a}}$ & $0.363^{\mathrm{a}}$ & 0.009 & $<0.001$ & $<0.001$ \\
\hline CLA trans -10, cis -12 & $0.010^{\mathrm{d}}$ & $0.020^{\mathrm{c}}$ & $0.020^{\mathrm{c}}$ & $0.021^{\mathrm{b}}$ & $0.022^{\mathrm{a}}$ & 0.063 & $<0.001$ & $<0.001$ \\
\hline CLA trans -11, cis -13 & $0.505^{\mathrm{d}}$ & $0.528^{\mathrm{c}}$ & $0.537^{\mathrm{c}}$ & $0.659^{\mathrm{b}}$ & $0.735^{\mathrm{a}}$ & 0.013 & $<0.001$ & $<0.001$ \\
\hline C18:2n-6 & $5.869^{\mathrm{a}}$ & $5.516^{\mathrm{b}}$ & $5.445^{\mathrm{bc}}$ & $5.375^{\mathrm{c}}$ & $5.364^{\mathrm{c}}$ & 0.028 & 0.001 & 0.001 \\
\hline $\mathrm{C} 18: 3 n-3$ & $0.152^{\mathrm{a}}$ & $0.151^{\mathrm{b}}$ & $0.150^{\mathrm{b}}$ & $0.148^{\mathrm{c}}$ & $0.149^{c}$ & 0.032 & 0.186 & 0.998 \\
\hline
\end{tabular}

abc Within a row, different superscript represents the significant differences by Tukey $\mathrm{P}<0.05$.

${ }^{1} \mathrm{SFA}=$ saturated fatty acids; MUFA= mono unsaturated fatty acids; PUFA= mono unsaturated fatty acids.

${ }^{2} \mathrm{SEM}=$ standard error of mean.

${ }^{3}$ Orthogonal polynomial contrast $\mathrm{P}<0.05$.

${ }^{4}$ Sum of all SFA: C10:0, C11:0, C12:0, C13:0, C14:0, C15:0, C16:0, C18:0, C20:0, C22:0 and C23:0.

${ }^{5}$ Sum of all MUFA: C14:1 cis-9, C15:1 cis-9, C16:1 trans-9, C16:1 cis-9, C18:1 trans-6-8, C18:1 trans-9, C18:1 trans-10, C18:1 trans11, C18:1 trans-12-14, C18:1 trans-15, C18:1 cis-9, C18:1 cis-11, C18:1 cis-12, C18:1 cis-13, C18:1 cis-14, and C18:1 cis-15.

${ }^{6}$ Sum of all PUFA: C18:2 trans-11, cis-15; C18:2 trans, trans isomers; C18:2 cis, cis isomers; C18:2 cis, trans isomers; CLA cis-9, trans-11; CLA trans-10, cis-12; CLA trans-11, cis-13; C18:2n-6; C18:3n-6; C18:3n-3; C20:2n-6; C20:3n-6; C20:3n-3; C20:5n3; C24:1n-9 and C22:6n-3. 
Clearly, the present matrix of flavonoids and essential oils derived from PL inhibited biohydrogenation, where the biohydrogenation of $\mathrm{C} 18: 2 \mathrm{n}-6$ and C18:3n-3 was abated, as poly unsaturated fatty acids (PUFAs) were observed. Reference to this shift in biohydrogenation, including the isomerization of FA by lipolysis, using flavonoids and essential oils of PL, is relatively limited. The application of only phenolic acid, quercetin, anthocyanin and eugenol for in vitro study is available in the literature (LOURENÇO et al., 2014; YANZA et al., 2018; BRYSZAK et al., 2019). In our study, PL encouraged rumen biohydrogenation to yield a more considerable PUFA accumulation, e.g. CLA cis-9, trans-11, CLA trans-10, cis-12 and CLA trans-11, cis-13, less saturated fatty acid as C18:0 and less mono-unsaturated fatty acid accumulation of C18:1 trans-11, rather than C18:2 trans-11, cis-15. It is reported that the biohydrogenation pathway could be shifted by the provision of flavonoids in the animal diet (YANZA et al., 2018), resulting in an increased amount of CLA cis-9, trans-11 produced in rumen fluid and milk (BRYSZAK et al., 2019).

As shown in table 4, enhanced PL supply interacted in the first biohydrogenation pathway of $\mathrm{C} 18: 2 \mathrm{n}-6$, resulted in the accumulation of $\mathrm{C} 18: 2$ cis-9 rather than C18:2 trans-11, cis15, which was observed to be different to other studies (LOURENÇO et al., 2014). The latter study reported that quercetin and eugenol were unable to alter the proportion of $\mathrm{C} 18: 2 \mathrm{cis}-9$ through the first biohydrogenation pathway of $\mathrm{C} 18: 2 \mathrm{n}-6$, although, it seemed successful at a slight reduction in C18:2 trans-11, cis-15. However, later biohydrogenation regarding the transformation of C18:1 trans-11 to C18:0 in these reports showed similar outcomes, addressing the limited supply of C18:1 trans-11, leading to a decrease in stearic acid (C18:0) accumulation. A possible reason for this difference concerns the FA isomer in the diet. LOURENÇO et al. (2014) fed rumen fermenters with more C18:3n-3 than $\mathrm{C} 18: 2 \mathrm{n}-6$. In contrast, the present study provided an abundance of C18:2n-6 from sunflower oil. This assertion could be true if the FA component was a major factor in modulating biohydrogenation (ROY et al., 2013). However, biohydrogenation efficiency is more complex because this process promotes rumen biohydrogenation bacteria and should be wisely considered for other factors, such as hydrogen supply (LOURENÇO et al., 2010). In this study, stearic bacteria (that were encouraged by the presence of PL) were responsible for undertaking CLA formation, but identification of specific ruminal microorganisms to confirm this was outside the scope of the present study. It is possible that small protozoa and big bacterial populations could influence lipase activity (LOURENÇO et al., 2010). Therefore, the change in rumen microorganisms, especially bacteria and protozoa, should not be ignored.

\section{CONCLUSION}

This study demonstrated that the matrix of flavonoids and essential oils in Piper betle powder can stimulate conjugated linoleic acid accumulation from biohydrogenation products, without interrupting nutrient fermentation. Methane production is also reduced. Another perspective of the use of these compounds can be assessed in vivo, where animals are fed with these bioactive compounds. It might be an alternative strategy to improve the quality of ruminant feeds.

Table 4 - The mean value of substrate incubated with Piper betle L. powder (PL) on the efficiency of lipolysis + isomerization (C18:2 n$6 \rightarrow \mathrm{C} 18: 2 \mathrm{c} 9 \mathrm{t} 11)$ and hydrogenation processes of $\mathrm{C} 18: 2 \mathrm{n}-6$ and $\mathrm{C} 18: 3 \mathrm{n}-3$ in incubations.

\begin{tabular}{|c|c|c|c|c|c|c|c|c|}
\hline \multirow[t]{2}{*}{ Parameter } & \multicolumn{5}{|c|}{ 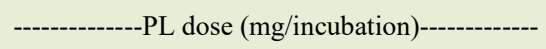 } & \multirow[t]{2}{*}{ SEM $^{1}$} & \multicolumn{2}{|c|}{-------Contrast ${ }^{2}------$} \\
\hline & 0 & 25 & 50 & 75 & 100 & & Linear & Quadratic \\
\hline $\mathrm{C} 18: 2 \mathrm{n}-6 \rightarrow \mathrm{C} 18: 2$ cis-9, trans -11 & $71.0^{\mathrm{b}}$ & $72.7^{\mathrm{a}}$ & $73.1^{\mathrm{a}}$ & $73.4^{\mathrm{a}}$ & $73.4^{\mathrm{a}}$ & 0.319 & 0.053 & 0.095 \\
\hline $\mathrm{C} 18: 3 \mathrm{n}-3 \rightarrow \mathrm{C} 18: 2$ trans -11, cis- 15 & 28.1 & 28.3 & 28.5 & 29.2 & 28.5 & 0.126 & 1.000 & 0.149 \\
\hline $\mathrm{C} 18: 2$ trans -11 , cis $-15 \rightarrow \mathrm{C} 18: 1$ trans -11 & $35.6^{\mathrm{d}}$ & $37.5^{\mathrm{cd}}$ & $41.1^{\mathrm{c}}$ & $42.3^{\mathrm{b}}$ & $44.0^{\mathrm{a}}$ & 0.471 & $<0.001$ & $<0.001$ \\
\hline $\mathrm{C} 18: 2$ cis -9, trans $-11 \rightarrow \mathrm{C} 18: 1$ trans -11 & 98.6 & 97.6 & 97.5 & 97.5 & 97.6 & 0.396 & 0.981 & 0.956 \\
\hline $\mathrm{C} 18: 1$ trans $-11 \rightarrow \mathrm{C} 18: 0$ & $83.8^{\mathrm{a}}$ & $53.7^{\mathrm{b}}$ & $43.4^{\mathrm{c}}$ & $41.5^{\mathrm{d}}$ & $40.6^{\mathrm{d}}$ & 2.338 & $<0.001$ & $<0.001$ \\
\hline
\end{tabular}

${ }^{a b c}$ Within a row, different superscript represents the significant differences by Tukey $\mathrm{P}<0.05$.

${ }^{1} \mathrm{SEM}=$ standard error of mean.

${ }^{2}$ Orthogonal polynomial contrast $\mathrm{P}<0.05$. 


\section{ACKNOWLEDGEMENTS}

The authors thank to all staffs of the center of scientific and technological equipment (CSTE), Suranaree University of Technology and the collective team (Nurrahim Dwi Saputra, Dian Candra Prasetyanti, Paiwan Panyakaew and Aliyatur Rosyidah) for their valuable helps. This research was funded by Suranaree University of Technology scholarship for ASEAN phase II (No. MOE5601/1350).

\section{DECLARATION OF CONFLICT OF INTERESTS}

The authors declare no conflict of interest. The founding sponsors had no role in the design of the study; in the collection, analyses, or interpretation of data; in the writing of the manuscript, and in the decision to publish the results.

\section{AUTHORS' CONTRIBUTIONS}

All authors contributed equally for the conception and writing of the manuscript. All authors critically revised the manuscript and approved of the final version.

\section{BIOETHICS AND BIOSSECURITY COMMITTEE APPROVAL}

All experimental procedures were approved and completed in accordance with the Rules of Animal Welfare of Suranaree University of Technology (SUT 4/2558) for animal protection used and/or applied for experimental purposes.

\section{REFERENCES}

ANDRÉS, S. et al. Effects of the inclusion of flaxseed and quercetin in the diet of fattening lambs on ruminal microbiota, in vitro fermentation and biohydrogenation of fatty acids. Journal of Agriculture Science, v.154, p.542-552, 2016. Available from: $<10.1017 /$ S0021859615001094>. Accessed: Dec. 8, 2015. doi: $10.1017 / \mathrm{S} 0021859615001094$.

ANDRIES, J. I. et al. Isoacids in ruminant nutrition: Their role in ruminal and intermediary metabolism and possible influences on performances - A review. Animal Feed Science and Technology, v.18, p.169-180, 1987. Available from: <http:/www.sciencedirect. com/science/article/pii/0377840187900691>. Accessed: Mar. 17, 1987. doi: 10.1016/0377-8401(87)90069-1.

AOAC. Official methods of analysis. 18th rev. ed. Maryland: AOAC International Suite 500, 2005. 72p.

BOECKAERT, C. et al. In vitro examination of DHA-edible micro algae: 1. Effect on rumen lipolysis and biohydrogenation of linoleic and linolenic acids. Animal Feed Science and Technology, v.136, p.63-79, 2007. Available from: <http://www.sciencedirect.com/ science/article/pii/S0377840106003348>. Accessed: Aug. 16, 2006. doi: 10.1016/j.anifeedsci.2006.08.015.

BRYSZAK, M. et al. Effects of berry seed residues on ruminal fermentation, methane concentration, milk production, and fatty acid proportions in the rumen and milk of dairy cows. Journal of Dairy Science, v.102, p.1257-1273, 2019. Available from: $<$ https://
www.sciencedirect.com/science/article/pii/S0022030218311019>. Accessed: Oct. 10, 2018. doi: 10.3168/jds.2018-15322.

CASTILLEJOS, L. et al. Effect of essential oil active compounds on rumen microbial fermentation and nutrient flow in in vitro systems. Journal of Dairy Science, v.89, p.2649-2658, 2006. Available from: $<$ http://www.sciencedirect.com/science/article/pii/ S0022030206723414>. Accessed: Feb. 21, 2006. doi: 10.3168/jds. S0022-0302(06)72341-4.

CHERDTHONG, A. et al. Effects of supplementation of Piper sarmentosum leaf powder on feed efficiency, rumen ecology and rumen protozoal concentration in thai native beef cattle. Animals, v.9, p.130, 2019. Available from: <http://europepmc.org/abstract/ MED/30997631>. Accessed: Mar. 29, 2019. doi: 10.3390/ani9040130.

DE WEIRDT, R. et al. A simulated mucus layer protects Lactobacillus reuteri from the inhibitory effects of linoleic acid. Beneficial Microbes, v.4, p.299-312,2013. Available from: $<$ https:// www.wageningenacademic.com/doi/pdf/10.3920/BM2013.0017>. Accessed: Dec. 5, 2013. doi: 10.3920/BM2013.0017.

DEHORITY, B. A. Rumen microbiology. Nottingham: Nottingham University Press, 2003. 372p.

DURMIC, Z. et al. Australian plants with potential to inhibit bacteria and processes involved in ruminal biohydrogenation of fatty acids. Animal Feed Science and Technology, v.145, p.271-284, 2008. Available from: <http://www.sciencedirect.com/ science/article/pii/S0377840107002829>. Accessed: May, 24, 2007. doi: 10.1016/j.anifeedsci.2007.05.052.

ERWIN, E. S. et al. Volatile fatty acid analyses of blood and rumen fluid by gas chromatography. Journal of Dairy Science, v.44, p.1768-1771, 1961. Available from: <http://www.sciencedirect. com/science/article/pii/S0022030261899566>. Accessed: May, 18, 2010. doi: 10.3168/jds.S0022-0302(61)89956-6.

FILÍPEK, J.; DVOŘÁK, R. Determination of the volatile fatty acid content in the rumen liquid: Comparison of gas chromatography and capillary isotachophoresis. Acta Veterinaria Brno, v.78, p.627-633, 2019. Available from: <https://actavet.vfu.cz/media/ pdf/avb_2009078040627.pdf>. Accessed: Jun. 30, 2019. doi: $10.2754 / \mathrm{avb} 200978040627$.

FOLCH, J. et al. A simple method for the isolation and purification of total lipides from animal tissues. Journal of Biological Chemistry, v.226, p.497-509, 1957. Available from: <https://www.ncbi.nlm.nih. gov/pubmed/13428781>. Accessed: Aug. 13, 1956.

GREENING, C. et al. Diverse hydrogen production and consumption pathways influence methane production in ruminants, The ISME Journal, v13, p.2617-2632, 2019. Available from: $<$ https://doi.org/10.1038/s41396-019-0464-2>. Accessed: Jun. 26, 2019. doi: 10.1038/s41396-019-0464-2.

JAYANEGARA, A. et al. Ruminal disappearance of polyunsaturated fatty acids and appearance of biohydrogenation products when incubating linseed oil with alpine forage plant species in vitro. Livestock Science, v.147, p.104-112, 2012a. Available from: $<$ http://www.sciencedirect.com/science/article/pii/ S1871141312001400>. Accessed: Apr. 18, 2012a. doi: 10.1016/j. livsci.2012.04.009.

JAYANEGARA, A. et al. Meta-analysis of the relationship between dietary tannin level and methane formation in ruminants from in 
vivo and in vitro experiments. Journal of Animal Physiology and Animal Nutrition, v.96, p.365-375, 2012b. Available from: $<$ http://dx.doi.org/10.1111/j.1439-0396.2011.01172.x>. Accessed: Apr. 22, 2011. doi: 10.1111/j.1439-0396.2011.01172.x.

KAPS, M.; LAMBERSON, W. R. Biostatistics for Animal Science. Oxfordshire: CABI, 2004. 459p.

LASHKARI, S.; JENSEN, S. K. Quantitative determination of conjugated linoleic acid and polyunsaturated fatty acids in milk with C17:0 as internal marker-Evaluation of different methylation procedures. Data in Brief, v.15, p.106-110, 2017. Available from: <http://www. sciencedirect.com/science/article/pii/S2352340917304535>. Accessed: Sep. 15, 2017. doi: 10.1016/j.dib.2017.09.022.

LODGE-IVEY, S. L. et al. Technical note: Bacterial diversity and fermentation end products in rumen fluid samples collected via oral lavage or rumen cannula. Journal of Animal Science, v.87, p.2333-2337, 2009. Available from: $<$ http://dx.doi.org/10.2527/jas.2008-1472>. Accessed: Dec. 5, 2014. doi: $10.2527 /$ jas.2008-1472.

LOURENÇO, M. et al. Effects of saponins, quercetin, eugenol, and cinnamaldehyde on fatty acid biohydrogenation of forage polyunsaturated fatty acids in dual-flow continuous culture fermenters. Journal of Animal Science, v.86, p.3045-3053, 2014. Available from: <http://dx.doi.org/10.2527/jas.2007-0708>. Accessed: Dec. 5, 2014. doi: 10.2527/jas.2007-0708.

LOURENÇO, M. et al. The role of microbes in rumen lipolysis and biohydrogenation and their manipulation. Animal, v.4, p.1008-1023, 2010. Available from: < https://www.cambridge. org/core/article/role-of-microbes-in-rumen-lipolysis-andbiohydrogenation-and-their-manipulation/588353D4E66B2D4E D12CFA9A8D694995>. Accessed: Mar. 23, 2010. doi: 10.1017/ S175173111000042X.

MARTY, R. J.; Demeyer, D. I. The effect of inhibitors of methane production of fermentation pattern and stoichiometry in vitro using rumen contents from sheep given molasses. British Journal of Nutrition, v.30, p.369-376, 1973. Available from: $<$ https:/www.cambridge.org/core/article/effect-of-inhibitors-ofmethane-production-of-fermentation-pattern-and-stoichiometryin-vitro-using-rumen-contents-from-sheep-given-molasses/ D55CEF383FE84F7337FFE689997439B4>. Accessed: Apr. 10, 2010. doi: 10.1079/BJN19730041.

MENKE, K. H.; Steingass, H. Estimation of the energetic feed value obtained from chemical analysis and in vitro gas production using rumen fluid. Animal Research and Development, v.28, p.7-55, 1988. Available from: <https://www.researchgate.net/ publication/286682081>. Accessed: Jan, 10, 2010.

MOSS, A. R. et al. Methane production by ruminants: its contribution to global warming, Annales de Zootechnie, v.49, p.231-253, 2000. Available from: <http://dx.doi.org/10.1051/ animres:2000119>. Accessed: Apr. 5, 2000. doi: 10.1051/ animres:2000119.

NEWBOLD, C. J. The role of ciliate protozoa in the rumen. Frontiers in Microbiology, v.6, p.1313-1313, 2015. Available from: <https:// www.ncbi.nlm.nih.gov/pubmed/26635774>. Accessed: Nov. 26, 2015. doi: $10.3389 /$ fmicb.2015.01313.

NRC. Nutrition requirements of small ruminants. Washington DC: The National Acadimies Press, 2007. 8p.
ORSKOV, E. R.; MCDONALD, I. The estimation of protein degradability in the rumen from incubation measurements weighted according to rate of passage. Journal Agriculture Science, v.92, p.499-503, 1970. Available from: <https:// www.cambridge.org/core/services/aop-cambridge-core/ content/view/E2DB4F2290E374E10E9800E512D127A7/ S0021859600063048a.pdf/estimation_of_protein_degradability_ in_the_rumen_from_incubation_measurements_weighted according to rate_of passage.pdf $>$. Accessed: Mar. $\overline{27}, 2009$. doi: $10.1017 / \mathrm{S} 0021859600063048$.

OSKOUEIAN, E. et al. Effects of flavonoids on rumen fermentation activity, methane production, and microbial population. BioMed Research International, v.8, 2013. Available from: <http:// dx.doi.org/10.1155/2013/349129>. Accessed: Aug. 26, 2013. doi: $10.1155 / 2013 / 349129$.

PAENGKOUM, P. et al. Molecular weight, protein binding affinity and methane mitigation of condensed tannins from mangosteenpeel (Garcinia mangostana L). Asian-Australasian Journal of Animal Science, v.28, p.442-1448, 2015. Available from: <http:// www.ncbi.nlm.nih.gov/pmc/articles/PMC4554851/>. Accessed: Apr. 11, 2015. doi: 10.5713/ajas.13.0834.

PANYAKAEW, P. et al. Medium-chain fatty acids from coconut or krabok oil inhibit in vitro rumen methanogenesis and conversion of non-conjugated dienoic biohydrogenation intermediates. Animal Feed Science and Technology, v.180, p.18-25, 2013. Available from: $<$ http://www.sciencedirect.com/science/article/pii/ S0377840112004026>. Accessed: Jan. 15, 2013. doi: 10.1016/j. anifeedsci.2012.12.005

PATRA, A. K.; SAXENA, J. A new perspective on the use of plant secondary metabolites to inhibit methanogenesis in the rumen. Phytochemistry, v.71, p.1198-1222, 2010. Available from: $<$ http:// www.sciencedirect.com/science/article/pii/S0031942210001858>. Accessed: Jun. 4, 2010. doi: 10.1016/j.phytochem.2010.05.010.

PURBA, R. A. P.; PAENGKOUM, P. Bioanalytical HPLC method of Piper betle L. for quantifying phenolic compound, watersoluble vitamin, and essential oil in five different solvent extracts. Journal of Applied Pharmaceutical Science, v.9, p.033-039, 2019. Available from: <https://www.japsonline.com/abstract. php?article_id $=2909 \&$ sts $=2>$. Accessed: May, 8, 2019. doi: 10.7324/JAPS.2019.90504.

PURBA, R. A. P. et al. The links between supplementary tannin levels and conjugated linoleic acid (CLA) formation in ruminants: A systematic review and meta-analysis. PLOS ONE, v.15, p.e0216187, 2020. Available from: <https://www.ncbi.nlm.nih. gov/pubmed/32168348>. Accessed: Mar. 13, 2020. doi: 10.1371/ journal.pone. 0216187 .

ROY, A. et al. Evaluating the performance, carcass traits and conjugated linoleic acid content in muscle and adipose tissues of Black Bengal goats fed soybean oil and sunflower oil. Animal Feed Science and Technology, v.785, p.43-82, 2013. Available from: <https://www.sciencedirect.com/ science/article/pii/S0377840113001892>. Accessed: Jul. 7, 2013. doi: 10.1016/j.anifeedsci.2013.07.004.

SZCZECHOWIAK, J. et al. Rumen fermentation, methane concentration and fatty acid proportion in the rumen and milk of dairy cows fed condensed tannin and/or fish-soybean oils blend. Animal Feed Science and Technology, v.216, p.93-107, 2016. Available from: $<$ http://www.sciencedirect.com/science/article/pii/ 
S0377840116301031>. Accessed: Mar. 16, 2016. doi: 10.1016/j. anifeedsci.2016.03.014.

TAVENDALE, M. H. et al. Methane production from in vitro rumen incubations with Lotus pedunculatus and Medicago sativa, and effects of extractable condensed tannin fractions on methanogenesis. Animal Feed Science and Technology, v.123124, p.403-419, 2005. Available from: <http://www.sciencedirect. com/science/article/pii/S037784010500180X > . Accessed: May, 23, 2005. doi: 10.1016/j.anifeedsci.2005.04.037.

TILLEY, J. M. A.; TERRY, R. A. A two-stage technique for the in vitro digestion of forage crops. Grass Forage Science, v.18, p.104-111, 1963. Available from: <http://dx.doi. org/10.1111/j.1365-2494.1963.tb00335.x>. Accessed: Jun. 22, 1963. doi: 10.1111/j.1365-2494.1963.tb00335.x.

VAN SOEST, P. J. et al. Methods for dietary fiber, neutral detergent fiber, and nonstarch polysaccharides in relation to animal nutrition, Journal of Dairy Science, v.74, p.3583-3597, 1991. Available from: <http://www.ncbi.nlm.nih.gov\%2Fpubmed $\% 2$ F1660498\% 3 Fdopt $\% 3$ DAbstract $\&$ ie $=$ utf-8\&sc us $=15708666796323421607>$. Accessed: Feb. 06, 1991. doi: 10.3168/jds.S0022-0302(91)78551-2.

WANAPAT, M. et al. Effects of plant herb combination supplementation on rumen fermentation and nutrient digestibility in beef cattle. Asian-Australasian Journal of Animal Science, v.26, p.1127-1136, 2013. Available from: $<\mathrm{http}: / /$ www.ajas.info/journal/view.php?number $=4753>$. Accessed: Mar. 23, 2013. doi: 10.5713/ajas.2013.13013.

WANAPAT, M. et al. Effect of ruminal $\mathrm{NH}_{3}-\mathrm{N}$ levels on ruminal fermentation, purine derivatives, digestibility and rice straw intake in swamp buffaloes. Asian-Australasian Journal of Animal Science, v.12, p.904-907, 1999. Available from: <https://www.ajas.info/journal/view.php?number=19481>. Accessed: Sep. 1, 1999. doi: 10.5713/ajas.1999.904.

YANZA, Y. R. et al. Coleus amboinicus (Lour.) leaves as a modulator of ruminal methanogenesis and biohydrogenation in vitro. Journal of Animal Science, v.96, p.4868-4881, 2018. Available from: <https://www.ncbi.nlm.nih.gov/ pmc/articles/PMC6247836/>. Accessed: Aug. 1, 2018. doi: $10.1093 / \mathrm{jas} / \mathrm{sky} 321$.

ZHOU, Y. Y. et al. Inhibition of rumen methanogenesis by tea saponins with reference to fermentation pattern and microbial communities in $\mathrm{Hu}$ sheep. Animal Feed Science and Technology, v.166-167, p.93-100, 2011. Available from: $<$ https://www.sciencedirect.com/science/article/pii/ S037784011100126X?via\%3Dihub>. Accessed: May, 5, 2011. doi: 10.1016/j.anifeedsci.2011.04.007. 